\title{
Bryophyllum pinnatum leaves ethanol extract inhibit maturation and promote apoptosis of systemic lupus erythematosus BALB/c mice B cells
}

\author{
Kusworini Handono, ${ }^{1}$ Tri W.I. Dantara, ${ }^{2}$ Elvira S. Dewi, ${ }^{3}$ Mirza Z. Pratama, ${ }^{4}$ Nurdiana ${ }^{5}$ \\ ${ }^{1}$ Department of Clinical Pathology, Faculty of Medicine, Universitas Brawijaya, Malang, Indonesia \\ 2 Biomedical Sciences Master Program, Faculty of Medicine, Universitas Brawijaya, Malang, Indonesia \\ ${ }^{3}$ Nursing Program, Faculty of Medicine, Universitas Brawijaya, Malang, Indonesia \\ ${ }^{4}$ Department of Internal Medicine, Faculty of Medicine, Universitas Brawijaya, Malang, Indonesia \\ ${ }^{5}$ Department of Pharmacology, Faculty of Medicine, Universitas Brawijaya, Malang, Indonesia
}

\section{ABSTRAK}

Latar belakang: Sel B memegang peranan penting pada lupus eritematosus sistemik (LES). Menargetkan sel B sebagai terapi LES merupakan pendekatan yang paling memungkinkan. Bryophyllum pinnatum dengan kandungan metabolit sekundernya memiliki agen imunomodulator potensial. Studi ini menyelidiki efek potensial dari ekstrak etanol daun B. pinnatum dalam menurunkan persentase maturasi, meningkatkan persentase apoptosis, dan menurunkan ekspresi NF-kB p65 sel $B$ mencit BALB/c dengan LES.

Metode: Studi in vitro dilakukan dengan melakukan kultur sel $B$ dari limpa mencit BALB/c dengan LESyang diinduksi pristan. Sel $B$ distimulasi oleh BAFF, LPS, IL-4, dan anti-CD40 menghasilkan CD19+>80\%. Sel B dikultur dengan menambahkan stimulan tersebut dengan dan tanpa ekstrak etanol daun B. pinnatum (dosis 0; 0,02; 0,1; atau 0,5 $\mu \mathrm{g} / \mathrm{ml}$ ) selama 72 jam pada suhu $37^{\circ} \mathrm{C}$. Persentase maturasi $(C D 19+C D 38+)$ dan apoptosis (Annexin $V+P I+)$ sel $B$ diukur menggunakan Flow cytometry. Analisis lebih lanjut untuk mengetahui ekspresi faktor transkripsi dari maturasi dan apoptosis sel $B, N F-k B$ p 65 , diukur menggunakan imunositokimia. Data yang terkumpul dianalisa menggunakan perangkat lunak SPSS versi 22.

Hasil: Uji Flow cytometry menunjukkan adanya penurunan signifikan terhadap persentase maturasi sel B pada semua dosis pemberian dan peningkatan signifikan terhadap persentase apoptosis sel B pada dosis 0,5 $\mathrm{\mu g} / \mathrm{ml}$. Hasil pemeriksaan imunositokimia menunjukkan penurunan signifikan terhadap ekspresi NF-kB p65 pada semua dosis. Persentase maturasi, apoptosis, dan ekspresi NF-kB p65 dari sel B memiliki korelasi satu sama lain.

Kesimpulan: Penelitian in vitro ini menunjukkan bahwa ekstrak etanol daun B. pinnatum menurunkan persentase maturasi, meningkatkan persentase apoptosis, dan menurunkan ekspresi $N F-\kappa B$ p 65 sel B mencit BALB/c dengan LES secara signifikan.

\section{ABSTRACT}

Background: B cells play a key role in systemic lupus erythematosus (SLE). Targeting B cells as SLE therapy is a plausible approach. This study investigated the potential effects of Bryophyllum pinnatum leaves with ethanol extract in decreasing percentages of maturation, increasing percentages of apoptosis, and decreasing NF- $\kappa B$ p65 expressions of SLE BALB/c mice B cells.

Methods: Culturing $B$ cells from pristane induced SLE BALB/c mice's spleen will resulted in this in vitro study. B cells were activated by BAFF, LPS, IL-4, and anti-CD40 yielding $\mathrm{CD} 19+>80 \%$. B cells were cultured by adding those stimulants with and without $B$. pinnatum leaves $(0,0.02,0.1$, or $0.5 \mu \mathrm{g} / \mathrm{ml})$ for 72 hours at $37^{\circ} \mathrm{C}$. Flow cytometry was performed to determine The Percentages of maturation (CD19+CD38+) and apoptosis (Annexin V+PI+) of $B$ cells. Further analysis to determine the expressions of transcription factor of maturation and apoptosis of B cells, NF-kB p65, were performed using immunocytochemistry. Data were analyzed using SPSS version 22.

Results: Flow cytometry assay showed significant decrease in percentages of maturation of B cells in all doses and significant increase in percentage of apoptosis of B cells in dose $0.5 \mu \mathrm{g} / \mathrm{ml}$. Immunocytochemistry results showed significant decrease expressions of NF-kB p65 in all doses. Percentages of maturation, apoptosis, and expressions of NFKB p65 of B cells were significantly correlated.

Conclusion: This in vitro study revealed that B. pinnatum leaves with ethanol extract decreased the percentages of maturation, increased the percentage of apoptosis, and decreased NF-kB p65 expressions of SLE BALB/c mice B cells significantly.

Keywords: B cells, Bryophyllum pinnatum, pristane, SLE

pISSN: 0853-1773 • eISSN: 2252-8083 • https://doi.org/10.13181/mji.v26i4.1899 • Med J Indones. 2017;26:253-60 - Received 07 Mar 2017 - Accepted 28 Dec 2017

Corresponding author: Tri W.I. Dantara, twidantara@gmail.com

Copyright @ 2017 Authors. This is an open access article distributed under the terms of the Creative Commons Attribution-NonCommercial 4.0 International License (http://creativecommons.org/licenses/by-nc/4.0/), which permits unrestricted non-commercial use, distribution, and reproduction in any medium, provided the original author and source are properly cited. 
Among many autoimmune disease, SLE is one of the complex ones. It display heterogenity in clinical manifestation followed by several abnormalities such as: autoantibodies formation, immune complex deposition, and damages to the organs. B cells play a key role in SLE such as secreting autoantibodies by plasma cells, providing antigens as co-stimulant to $\mathrm{T}$ cells, inducing dendritic cell (DC) immunogenicly, producing proinflammatory cytokines and chemokines, and influencing the regulation of immunity and limphogeneity in SLE. ${ }^{1}$ The plausible approach in therapy of SLE includes supression of autoantibodies production due to B cells maturation and proliferation, or B cell function modulation. ${ }^{2}$

To investigate the mechanisms of the disease, we need to understand how important are several SLE animal models to the mechanisms itself. One model, characterized by the development of several autoantibodies and clinical manifestation, is called pristane induced lupus model. ${ }^{3}$ Intraperitoneal injection of pristane in BALB/c mice causes a SLE with high levels of immunoglobulin G (IgG), anti-double stranded DNA (anti-dsDNA), anti-Smith (anti-Sm), antiRNP, anti-Su, anti-ribosomal P, and other lupusrelated autoantibodies starting 12 weeks after injection. ${ }^{4}$ This model may cause abnormalities in interferon production followed by defective clearance of apoptotic cells and over-active B-cell signalling. This is a clear impact of pristineinduced SLE BALB/c mice model. ${ }^{5}$

Due to earlier diagnosis and better treatment options of SLE, the prognosis has markedly improved in the last decades. ${ }^{6}$ In the past decade, we have learn to fully understand the process behind pathogenesis of SLE, which led to a more effective therapeutic approach ${ }^{7}$. One of the examples of recent therapeutic approach is biologic agent for SLE. Biologic agent has generated substantial research interest for developing therapy of several autoimmune diseases. $^{8}$

In 2011, biologic agent belimumab, a monoclonal antibody targeting human B cell activating factor (BAFF), was shown in randomized clinical trials to be efficacious in SLE and has now become the first approved targeted therapy for SLE. ${ }^{8}$ Belimumab treatment is quite expensive. The total cost for the first year of treatment is around $\$ 28,000$. ${ }^{9}$
The study of BAFF and its clinical inhibition are gaining notable interests over the year. It was mainly due to the test of similar biologic agent in clinical trials. ${ }^{10}$ Therefore, more effective drugs with an affordable monetary cost are urgently needed. In nature, there are many natural compounds which can be developed to treat SLE because their effects in modulate immunity.

B. pinnatum is a wild perennial succulent herb that is usually used as a traditional medicinal plant in tropical countries like Africa, Indonesia, and India. B. pinnatum is known by numerous vernacular names, such as life plant, love plant, and miracle leaf. ${ }^{11}$ It has been used in anthroposophic medicine to treat various disorders caused by hyperactive conditions. Various secondary metabolites of $B$. pinnatum, especially flavonoid and bufadienolid, have been reported by several pharmacological studies as broad spectrum therapeutic potential such as immunomodulatory, cytotoxic and antitumor promotingactivity, antiallergic, anti-inflammatory, antioxidant, analgesic, and antihypertensive. Other constituents of $B$. pinnatum include steroids, triterpenes, phenanthrenes, and some ubiquitous compounds. ${ }^{12}$ Despite having broad spectrum therapeutic potential, B. pinnatum's immunomodulatory activity in general and B cell apoptosis inducing property in particular have not been explored as yet. Therefore, this study evaluated whether B. pinnatum could decrease the percentages of maturation, increase the percentages of apoptosis, and decrease NF- $\mathrm{kB}$ p65 expressions of B cells furthermore prevent the development of pristane-induced lupus in SLE BALB/c mice B cells.

\section{METHODS}

\section{Animals}

This experimental and randomized post-test only controlled group design study was conducted in Malang, East Java, Indonesia between April and December 2016. Female BALB/c mice aged 6-8 weeks (25-35g) were purchased and certified from Pusat Veteriner Farma (Surabaya, East Java, Indonesia). All the BALB/c mice were housed at Pharmacology Laboratory of Universitas Brawijaya and acclimatized in the laboratory for 1 week prior to the experiments. The housing conditions were controlled, with a 
room temperature and a diurnal 12-hour light/ dark cycle. All experimental protocols described in this study were approved by the Health Research Ethics Committee, Faculty of Medicine, Universitas Brawijaya (Ethical clearance approval number: No. 328/EC/KEPK/05/2015).

\section{Induction and treatment of pristane-induced SLE in mice}

Female BALB/c mice were treated with single injection of pristane (Santa Cruz, California, USA) $0.5 \mathrm{ml}$ intraperitoneally per mice. Spleen and serum were collected 16 weeks after the pristane injection. Clinical manifestations were also observed after 16 weeks of pristane injection. Consistent with our previous findings, treatment with single injection of pristane 0.5 $\mathrm{ml}$ intraperitoneally increased antinuclear antibodies (ANA) serum titers compared with control group as early 16 weeks (data not shown).

\section{Plant material}

B. pinnatum leaves were collected from Batu, East Java, Indonesia in August 2016. Leaves were identified and authenticated at Unit Pelaksana Teknis (UPT) Balai Materia Medica, Batu, East Java, Indonesia. They were air dried and grounded into fine powder. A sample specimen was deposited at the herbarium.

\section{Extract preparation}

Dried and powdered leaves (100 g) were exhaustively extracted with ethanol $(900 \mathrm{ml})$ by static maceration at room temperature every 24 hours for 3 times. The ethanol extract was filtered and evaporated under a rotary vacuum evaporator at controlled temperature $\left(70-75^{\circ} \mathrm{C}\right)$. This extract was filtered through whatman paper no. $42(125 \mathrm{~mm})$ and every $1 \mathrm{mg}$ of stock solution was prepared in $1 \mathrm{ml}$ $(0.01 \%)$ of dimethyl sulfoxide (DMSO). The DMSO concentration was ignored because it was lower than $1 \%$.

\section{Cell preparation and culture}

Mice were sacrificed by cervical dislocation 16 weeks after receiving the single pristane injection, and spleens were collected for analysis. Cell suspensions were prepared by homogenization in a tissue grinder. $B$ cell enriched suspensions were obtained by stimulating suspensions with $100 \mathrm{ng} / \mathrm{ml} \mathrm{BAFF}$
(Biolegend), $10 \mu \mathrm{g} / \mathrm{ml}$ anti-CD40 antibody (Biolegend), $20 \mu \mathrm{g} / \mathrm{ml}$ LPS from Escherichia coli (Sigma-Aldrich), and $50 \mathrm{ng} / \mathrm{ml}$ IL-4 (Biolegend). Our preliminary experiments demonstrated that this procedure yielded an enriched B-cell population $>80 \%$ CD19+ cells as determined by flow cytometry analysis (data not shown). B cells enriched suspensions were cultured at a concentration of $5 \times 10^{5}$ cells $/ \mathrm{ml}$ in Roswell Park Memorial Institute (RPMI) 1640 medium (Gibsco, Thermo Fisher Scientific) supplemented with $10 \%$ FBS and $100 \mathrm{U} / \mathrm{mL}$ penicillin-streptomycin (Sigma-Aldrich, USA), those stimulating factors mentioned above, with or without ethanol extract of $B$. pinnatum leaves $(0,0.02,0.1$, or $0.5 \mu \mathrm{g} / \mathrm{ml})$ for 72 hours at $37^{\circ} \mathrm{C}$ without DMSO control.

\section{CD19 and CD38}

To determine the immunomodulatory activity of B. pinnatum leaves with ethanol extract against $\mathrm{B}$ cells maturation process in vitro, expressions of typical markers (CD19 and CD38) associated with the maturation status of $\mathrm{B}$ cells were measured. After 72 hours, cells were harvested for flow cytometry analysis of the percentages of CD19+CD38+ B cells. Cells were labeled with fluorescein isothiocyanate (FITC)-anti mouse CD19 (Biolegend) and phycoerythrin (PE) antimouse CD38 (Biolegend) following the protocol indicated by the manufacturer.

\section{Apoptosis assay}

Apoptosis of B cells were measured using flow cytometry staining with the FITC annexin $\mathrm{V}$ detection kit with propidium iodide (PI) (Biolegend). In detail, cells were stained for 20 minutes at room temperature in the dark with an annexin V. Afterwards, PI was added to the wells, and cells were further incubated for 5 minutes. After staining, cells were analyzed by flow cytometry to determine the percentages of apoptotic cells (Annexin V+PI+).

\section{Detection NF-kB p65 expressions by immunocytochemistry}

To understand the molecular mechanisms of B cells depletion, the expressions of protein controller of maturation and apoptosis of B cells, NF-kB p65, were examined using immunocytochemistry labeled with NF-kB p65. Immunocytochemistry was performed by using the streptavidinbiotin/indirect immunoperoxidase method. 
Thin smears were fixed in poly-L-lysin coated slides by methanol for 30 minutes. They were washed in FBS 3 times for 5 minutes, and endogenous peroxidase was blocked using 3\% hydrogen peroxide in methanol for 20 minutes at room temperature. Smears were washed in FBS 3 times for 5 minutes. Unspecific proteins were blocked using blocking buffer (3\% FBS and $0.25 \%$ Triton $\mathrm{X}-100$ ) for 6 minutes at room temperature. The primary antibody (NF-kB p65, Santa Cruz) was applied at the desired dilution, and slides were incubated overnight at $4^{\circ} \mathrm{C}$ in a moist chamber. They were washed 3 times with FBS and further incubated with the secondary antibody (Biotin conjugate) for 60 minutes, washed in FBS, and incubated with horseradish peroxidase for 40 minutes. By washing the slides again with FBS three times, and rinsing it with distilling water, can resulted in the development of the color 3-3' diaminobenzidine and hydrogen peroxide. Hematoxylin can be used afterwards to counterstain the smears. The final output, the brown reaction product (NF- $\kappa \mathrm{B}$ p65), then would be mounted and observed under the light microscope. Total numbers of apoptotic cells were determined by calculating the number of brown color cells in 10 fields of view then divided by 10 .

\section{Statistical Analysis}

The percentages of CD19+CD38+, Annexin $\mathrm{V}+\mathrm{PI}+$, and NF- $\mathrm{BB}$ p65 expressions of B cells were tested for normality using the Kolmogorov Smirnov test and for homogeneity variances prior to further statistical analysis. The data were normally distributed and were expressed as means \pm standard error of mean (SEM). Significant differences among groups were analyzed by one way ANOVA followed by Tukey's post-test for multiple comparisons using SPSS software, version 22 (IBM Corp., Armonk, NY, USA). Correlations between the percentages of CD19+CD38+, Annexin V+PI+, and NF- $\kappa$ B p65 expressions of $B$ cells were examined by Pearson's correlation coefficient. Differences were considered statistically significant at $p$ $<0.05$.

\section{RESULTS}

\section{Pristane-induced SLE BALB/c mice model}

Clinical evidence of inflammation of joints, gait changes, alopecia, and ascites occurred 16 weeks after pristane injection in BALB/c mice (Figure 1). The first sign of joint inflammation was seen at 12 weeks after pristane injection (Figure 1A).

\section{B. pinnatum leaves with ethanol extract inhibited maturation of pristane-induced SLE BALB/c mice B cells}

This study showed that treatment with 0 , $0.02,0.1$, or $0.5 \mu \mathrm{g} / \mathrm{ml} \mathrm{B}$. pinnatum leaves with

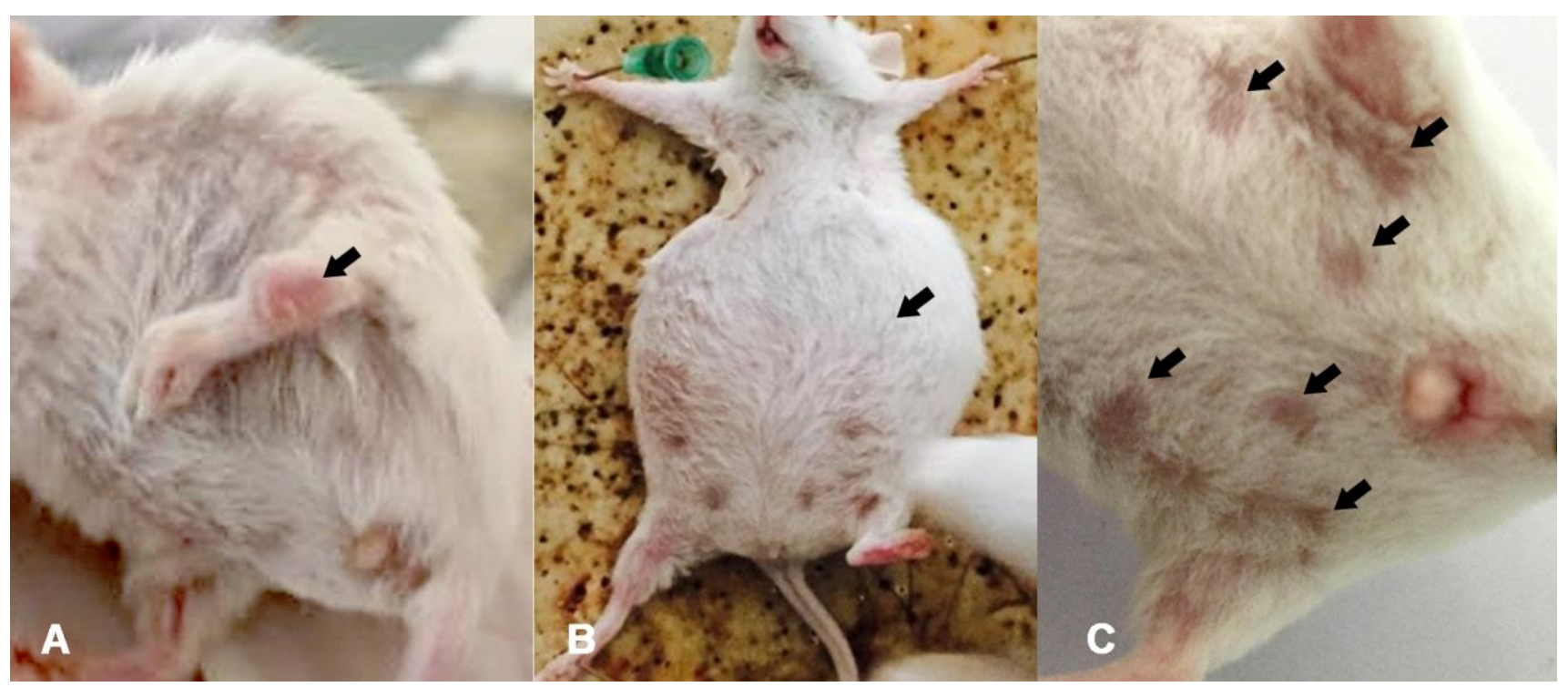

Figure 1. SLE clinical manifestations after 16 weeks of pristane injection. A) Joint inflammation was seen at 12 weeks after pristane injection (black arrow); B) Production of abdominal fluid or ascites (black arrow); C) The most frequent signs were alopecia (black arrows) 
ethanol extract inhibited maturation rates of $6.64 \pm 0.14 \%, \quad 5.90 \pm 0.46 \%, \quad 5.54 \pm 0.31 \%$, and $4.89 \pm 0.37 \%$ (Figure 2), respectively. CD19+CD38 ${ }^{+}$ $B$ cells percentages were significantly decreased compared to the untreated group $(\mathrm{p}=0.006, \mathrm{p}=0$, and $\mathrm{p}=0$, respectively) (Figure $3 \mathrm{~A}$ ).

\section{B. pinnatum leaves with ethanol extract promoted apoptosis of pristane-induced SLE BALB/c mice B cells}

This study showed that treatment with $0,0.02$, 0.1 , or $0.5 \mu \mathrm{g} / \mathrm{ml} \mathrm{B}$. pinnatum leaves with ethanol extract promoted apoptotic rates of $35.80 \pm 1.54 \%$, $38.41 \pm 5.19 \%, 40.28 \pm 2.51 \%$, and $44.01 \pm 2.60 \%$ (Figure 2), respectively. B cells treated with $0.5 \mu \mathrm{g} / \mathrm{ml}$ B. pinnatum leaves with ethanol extract significantly increased the percentage of apoptosis compared to the untreated group $(p=0.002)$. However, lower dose treatment of 0.02 and $0,1 \mu \mathrm{g} / \mathrm{ml}$ B. pinnatum leaves with ethanol extract showed insignificant effect on increasing the percentage of apoptosis compared to the untreated group $(\mathrm{p}=0.520$ and $\mathrm{p}=0.114$, respectively) (Figure $3 \mathrm{~B}$ ).
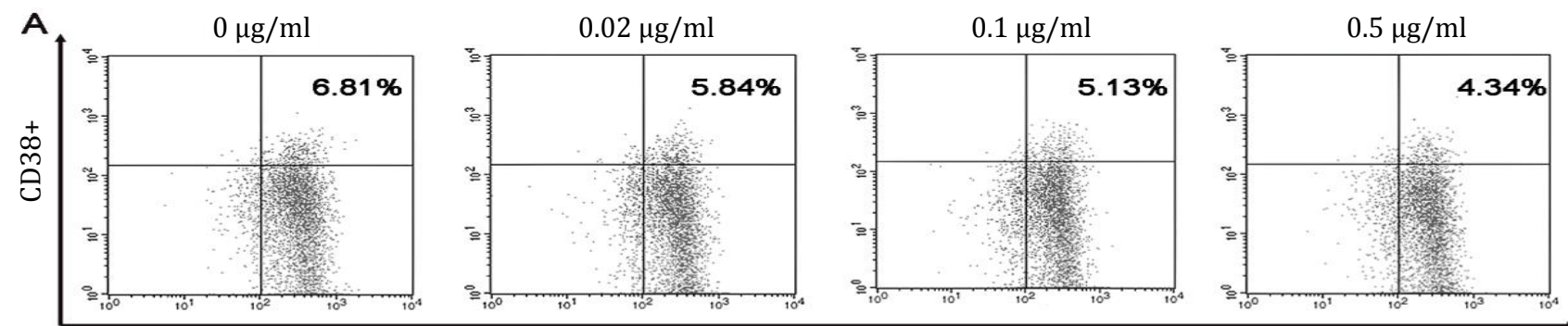

CD19+
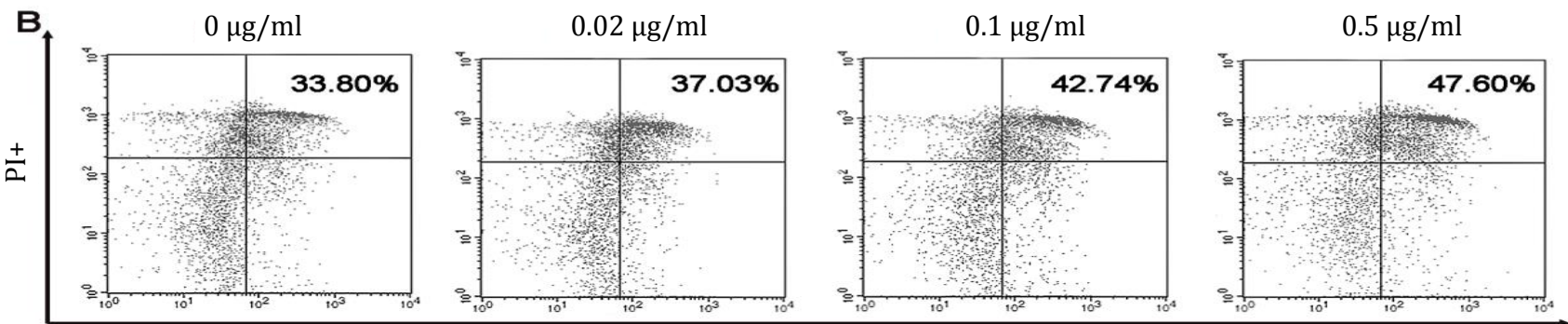

Annexin V+

Figure 2. Dot plots of B cells maturation and apoptosis in vitro. Spleen of pristane-induced SLE BALB/c mice model cultured with BAFF, anti-CD40, LPS, IL-4 and without or with different doses of $B$. pinnatum leaves with ethanol extract $(0,0.02,0.1$, or $0.5 \mu \mathrm{g} /$ $\mathrm{ml}$ ). Cells were harvested and measured percentages of maturation (CD19+CD38+) (A) and apoptosis (Annexin V+PI+) (B) of B cells using flow cytometry
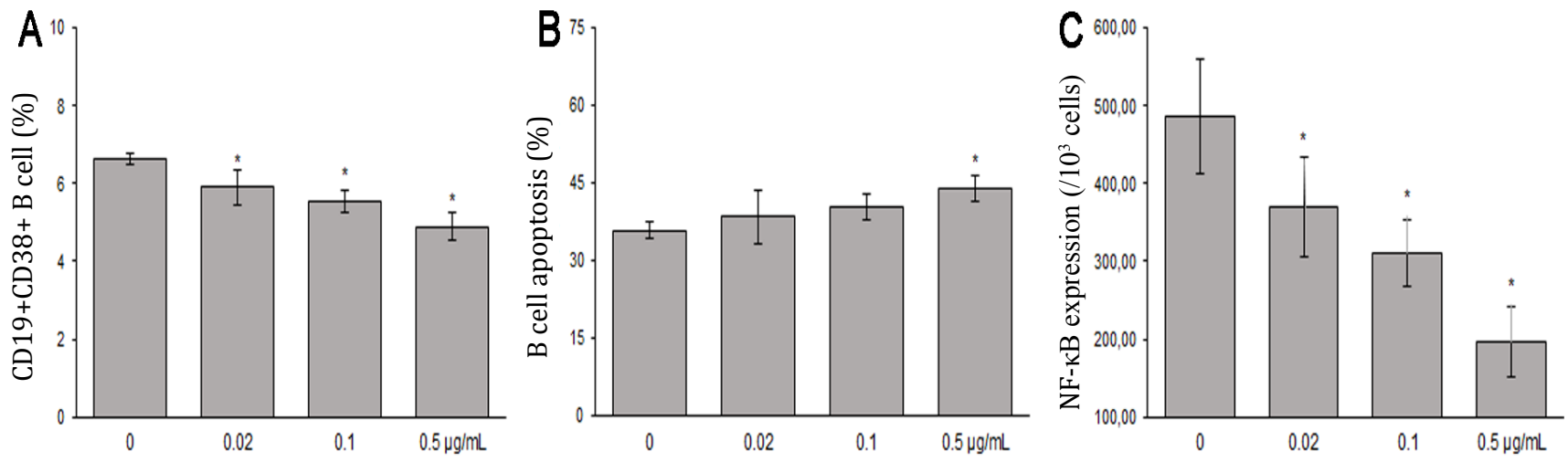

Figure 3. The effects of $B$. pinnatum leaves with ethanol extract on B cells in vitro. A) B. pinnatum leaves with ethanol extract inhibit maturation (CD19+CD38+) of B cells; B) B. pinnatum leaves extract promote apoptosis (Annexin V+/PI+) of B cells; C) B. pinnatum leaves with extract decrease expressions of NF- $\kappa B$ p65 (mean \pm SD; $n=6,{ }^{*}<<0.05$ ) 


\section{B. pinnatum leaves with ethanol extract decreased NF-kB p65 in pristane-induced SLE BALB/c mice B cells}

B. pinnatum leaves with ethanol extract group had significant lower expressions of NF- $\kappa \mathrm{B}$ p65 compared to the untreated group $(\mathrm{p}=0.013$,

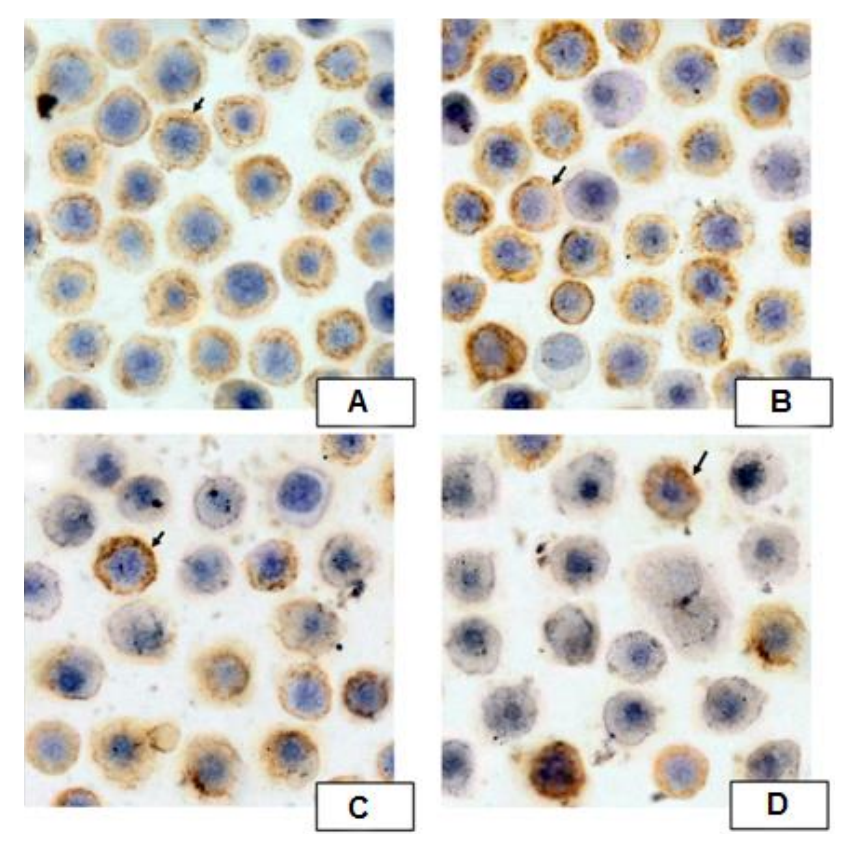

Figure 4. Expressions of NF-kB p65 by Immunocytochemistry. Spleen of pristane-induced SLE BALB/c mice model cultured with BAFF, anti-CD40, LPS, IL-4 and treated without or with different doses of B. pinnatum leaves with ethanol extract $(0,0.02,0.1$, or $0.5 \mu \mathrm{g} / \mathrm{ml})$ for 72 hours. Cells were processed for immunocytochemistry using NF- $\mathrm{kB}$ p65 antibody as described in Materials and Methods $\mathrm{p}<0.01$, and $\mathrm{p}<0.01$, respectivelly). B. pinnatum leaves with ethanol extract decreased the expressions of NF- $\kappa \mathrm{B}$ p65 (Figure 4).

Correlations between the percentages of maturation, apoptosis, and expressions of NFкB p65 of B cells

The percentages of maturation of $B$ cells had moderate and significant correlation with apoptosis of B cells $(r=-0.512, p<0.05)$. Significant and strong correlation was observed in the percentages of maturation and NF- $\kappa B$ p65 expressions of B cells ( $\mathrm{r}=0.849, \mathrm{p}<0.001)$. Significant and moderate correlation was observed in the percentage of apoptosis and NF- $\kappa$ B p65 expressions of B cells $(n=6, r=-0.692$, $\mathrm{p}<0.001$ ) (Figure 5).

\section{DISCUSSION}

B. pinnatum is a wild plant that has been proven to have benefits as anti-infammatory, antitumor, and immunomodulatory agents. ${ }^{11}$ Phytochemistry studies showed that B. pinnatum contains elements such as alkaloids, phenol, flavonoids, tannins, anthocyanin, glycosides, bufadienolide, saponins, coumarin, sitosterol, quinine, carotenoids, tocopherol, mucilago, lignin, and lectin. ${ }^{13-15}$ The therapeutic effects of $B$. pinnatum in pristane induced SLE BALB/c mice B cells explored in this study. B. pinnatum leaves with ethanol extract decreased percentages of
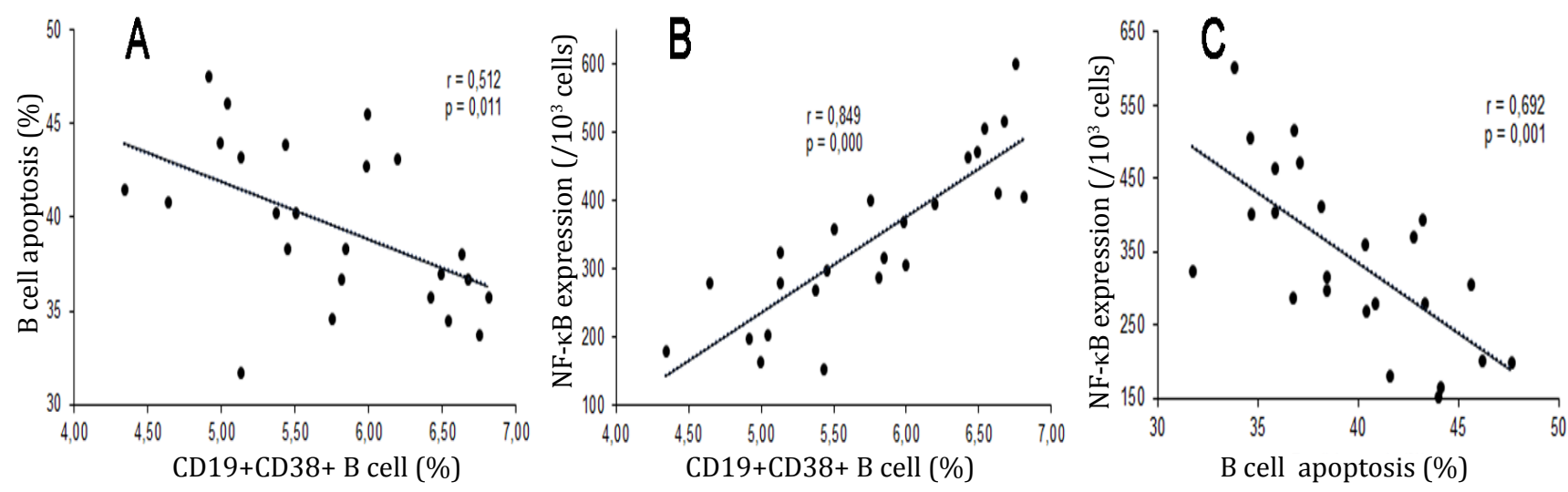

Figure 5. Correlations between percentages of maturation, apoptosis, and NF- $\kappa$ B p65 expressions of B cells. Diagrams showed correlations among the percentages of maturation (CD19+CD38+), apoptosis (Annexin $\mathrm{V}+\mathrm{PI}+$ ), and expressions of NF- $\kappa \mathrm{B}$ p65 of B Cells. A) Significant and moderate correlation was observed in percentages of maturation and apoptosis of $B$ cells $(r=-0.512$, $\mathrm{p}=0,011)$; B) Significant and strong correlation was observed in the percentages of maturation and expressionsNF- $\mathrm{B}$ p65 of B cells ( $r=0.849, p=0,000)$; C) Significant and moderate correlation was observed in the percentage of apoptosis and expressionsNF$\kappa \mathrm{B}$ p65 of B cells $(n=6, r=-0.692, \mathrm{p}<0,001)$ 
maturation (CD19+CD38+) of B cells, increased the percentage of apoptosis (Annexin $\mathrm{V}+\mathrm{PI}+$ ), and decreased NF- $\kappa B$ p65 expressions in pristaneinduced SLE BALB/c mice B cells in vitro.

The parenteral use of $B$. pinnatum has been granted permission by the German and Swissmedic E commission. ${ }^{16}$ B. pinnatum preparations are available in tablets, powders, and parenterals (Bryophyllum 5\%), produced by Weleda AG, and used as a tocolytic agent in premature pregnancy and various other medical conditions as well. ${ }^{11}$ Previous study compared various parenteral agents and showed that administering of Bryophyllum 5\% did not have significant effects to apoptosis and necrosis of lymphocytes and DC in vitro. However, this study showed different findings compared to Gründemann et al. ${ }^{17}$ The administration of B. pinnatum leaves with ethanol extract increased percentages of B cells apoptosis.

Several strategies have been developed to suppress the production of autoantibodies by depletion of B cells, inhibition of B cells proliferation, and modulation of B cells. Recent studies were still focused on the mechanism of BAFF in depleting B cells. ${ }^{18}$ This study performed B cells activation models by stimulating it with BAFF, IL-4, LPS, and anti-CD40 antibody. This study suggested that $B$. pinnatum leaves with ethanol extract could decrease $\mathrm{B}$ cells maturation, NF- $\kappa \mathrm{B}$ expressions, and increase apoptosis of $\mathrm{B}$ cells. The limitation of this study was that it did not compare the effects of BAFF, IL-4, LPS, and anti-CD40 antibody stimulation respectively. Further research may require to understand the mechanisms of $B$. pinnatum metabolites in disrupting the ligandreceptor binding of B cells.

Bufadienolide is one of the main active metabolites in B. pinnatum. About 40.5-52 mg bufadienolide contained in every 100 grams of B. pinnatum. ${ }^{12}$ Our unpublished in silico study was conducted to understand the affinity of bufadienolide active compounds (Bryophillin A, Bryophillin B, and Bryotoxin B) in B. pinnatum against BAFF and its receptors: BAFF-R, TACI, and BCMA. Docking results suggested that those B. pinnatum compounds interacted with BAFF-R, TACI, BCMA and BAFF through hydrogen bonds and hydrophobic interactions. These results showed that bufadienolide active compounds disrupted BAFF interactions with its receptors.
These study results demonstrated that single dose of pristane injection intraperitonialy in BALB/c mice induced arthritis, alopecia, and ascites after 16 weeks of injection. These results supported our previous study that manifestations of SLE such as arthritis, alopecia, and ascites appear in BALB/c mice model after single dose of $0.5 \mathrm{mg}$ pristane injection intraperitonealy. ${ }^{19}$ Based on the kinetics of autoantibody development following exposure to pristane, 16 weeks of the first clinical manifestation period was chosen. ${ }^{20}$ The results showed that pristane induced immunity disregulation and induced autoreactive of B cells shown by producing autoantibodies like ANA. ${ }^{19,21}$ ANA serum titersare increased in the week 16.

The clinical impact of this study is expected to find a new complementary therapy derived from the original leaves of Indonesia, B. Pinnatum, to improve the success of therapy in patients with SLE in Indonesia. However, this study still can not explain which specific secondary metabolic content has a role to the maturation and induction of $B$ cell apoptosis. Besides, we also have not compared the effect of $B$. pinnatum leaves with ethanol extract between each stimulant to know specifically the role of secondary metabolite contained to the activation pathway of B cells development. The study would have yielded different results if a negative or normal control group had been included. Thus, further research should address this limitation in order to reveal more important findings.

In conclusion, B. pinnatum leaves with ethanol extract decreased the percentages of maturation (CD19+CD38+) of $B$ cells, increased the percentage of apoptosis (Annexin $\mathrm{V}+\mathrm{PI}+$ ), and decreased NF- $\kappa \mathrm{B}$ p65 expressions in pristaneinduced SLE BALB/c mice B cells in vitro. Further studies in other lupus models and good-designed clinical trials are required to confirm these studies and identify its therapeutic effects, especially in humans.

\section{Conflicts of interest}

The authors affirm no conflict of interests in this study.

\section{Acknowledgment}

We thank Mr. Wahyudha Ngatiril Lady, Mrs. Bunga Prihardina, and Mrs. Ami Magfiroh for their expert technical assistance in this study. 


\section{REFERENCES}

1. Jacob N, Stohl W. Autoantibody-dependent and autoantibody-independent roles for B cells in systemic lupus erythematosus: past, present, and future. Autoimmunity. 2010; 43(1): 84-97.

2. Pateinakis P, Pyrpasopoulou A. Targeting the B-cell pathway in lupus nephritis: current evidence and future perspectives. Sci World J. 2013;2013:745239.

3. Leiss H, Niederreiter B, Bandur T, Schwarzecker B, Blüml S, Steiner G, et al. Pristane-induced lupus as a model of human lupus arthritis: evolvement of autoantibodies, internal organ and joint inflammation. Lupus. 2013;22(8):778-92.

4. Reeves WH, Lee PY, Weinstein JS, Satoh M, Lu L. Induction of autoimmunity by pristane and other naturally occurring hydrocarbons. Trends Immunol. 2009;30(9):455-64.

5. Zhuang H, Szeto C, Han S, Yang L, Reeves WH. Animal models of interferon signature positive lupus. Front Immunol. 2015;6(291):1-6.

6. Postal M, Costallat LT, Appenzeller S. Biological therapy in systemic lupus erythematosus. Int J Rheumatol. 2012;2012:578641.

7. Anolik JH. B cell biology: implications for treatment of systemic lupus erythematosus. Lupus. 2013;22(4):342-9.

8. Furie R, Petri M, Zamani O, Cervera R, Wallace DJ, Tegzová D, et al. A phase III, randomized, placebocontrolled study of belimumab, a monoclonal antibody that inhibits B lymphocyte stimulator, in patients with systemic lupus erythematosus. Arthritis Rheum. 2011;63(12):3918-30.

9. Hahn BH. Belimumab for systemic lupus erythematosus. N Engl J Med. 2013;368(16):1528-35.

10. Vincent FB, Morand EF, Schneider P, Mackay F. The BAFF/APRIL system in SLE pathogenesis. Nat Rev Rheumatol. 2014;10(6):365-73.

11. Fürer K, Simões-Wüst AP, Von Mandach U, Hamburger M, Potterat O. Bryophyllum pinnatum and related species used in anthroposophic medicine: constituents, pharmacological activities, and clinical efficacy. Planta Med. 2016;82(11-12):930-41.

12. Oufir M, Seiler C, Gerodetti M, Gerber J, Fürer K, Mennet-von EM, et al. Quantification of bufadienolides in Bryophyllum pinnatum leaves and manufactured products by UHPLC-ESIMS/MS. Planta Med. 2015;81(12-13):1190-7.

13. Anjoo K, Kumar SA. Microscopical and preliminary phytochemical studies on aerial part (leaves and stem) of Bryophyllum Pinnotum Kurz. Phcog J. 2010;2(9):254-9.

14. Nwali BU, Okaka ANC, Ibiam UA, Aja PM. Phytochemical composition of Bryophyllum pinnatum leaves. Int J Adv Biol Res. 2012;2(4):614-6.

15. Zhang X-A, Zhang S, Yin Q, Zhang J. Quercetin induces human colon cancer cells apoptosis by inhibiting the nuclear factor-kappa B pathway. Pharmacogn Mag. 2015;11(42):404-9.

16. Simões-Wüst AP, Jeschke E, Mennet M, Schnelle M, Matthes $\mathrm{H}$, von Mandach U. Prescribing pattern of Bryophyllum preparations among a network of anthroposophic physicians. Forsch Komplementmed. 2012;19(6):293-301.

17. Gründemann C, Diegel, C, Sauer B, Garcia-Käufer M, Huber R. Immunomodulatory effects of preparations from Anthroposophical Medicine parenteral use. BMC Complement Altern Med. 2015;15:219.

18. Czabotar PE, Lessene G, Strasser A, Adams JM. Control of apoptosis by the BCL-2 protein family: implications for physiology and therapy. Nat Rev Mol Cell Biol. 2014;15(1):49-63.

19. Kalim H, Handono K, Khalasa T, Pratama MZ, Dantara TWI, Wulandari AP, et al. Immune modulation effects of curcumin in pristane induced lupus mice. Indian J Rheumatol. 2017;12(2):86-93.

20. Pawar RD, Goilav B, Xia Y, Zhuang H, Herlitz L, Reeves WH. Serum autoantibodies in pristane induced lupus are regulated by neutrophil gelatinase associated lipocalin. Clin Immunol. 2014;154(1):49-65.

21. Yaniv G, Twig G, Shor DBA, Furer A, Sherer Y, Mozes O, et al. A volcanic explosion of autoantibodies in systemic lupus erythematosus: a diversity of 180 different antibodies found in SLE patients. Autoimmun Rev. 2015;14(1):75-9. 